\title{
Primary Hippocampal Cell Culture and Its Application in Medical Researches
}

\author{
Nur Atik, ${ }^{1}$ Alfya Nandika, ${ }^{2}$ Erda Avriyanti, ${ }^{3}$ Tryando Bhatara, ${ }^{4}$ Raden Angga Kartiwa ${ }^{5}$ \\ ${ }^{1}$ Department of Biomedical Sciences, ${ }^{2}$ Medical Undergraduate Study Program, ${ }^{3}$ Department of Dermatology and \\ Venereology, Faculty of Medicine, Universitas Padjadjaran, Bandung, Indonesia, ${ }^{4}$ Department of Histology and \\ Cell Biology, Faculty of Medicine, Universitas Islam Bandung, Bandung, Indonesia, ${ }^{5}$ Department of Opthalmology, \\ Faculty of Medicine, Universitas Padjadjaran, Bandung Bandung, Indonesia
}

\begin{abstract}
Studies in neuroscience can be performed in vitro and in vivo. In vivo studies will show significant results, but it is difficult to do and time-consuming. Primary hippocampal cell culture widely has used in neurobiological studies such as identifying the cellular mechanism of proteins, neuronal activity, and characteristics. The results of studies conducted on this cell culture will be very useful in discovering pathogenesis of a disease, the effect of a substance on the neuron, and neural basis of memory and learning. However, currently in Indonesia, primary hippocampal cell culture is still rare and difficult to do. The purpose of this study was to demonstrate that primary hippocampal cell culture can be done and developed in Indonesia and to review the application of it in medical researches. The study was an experimental study by obtaining neurons from animal's hippocampus was conducted in 2015-2018 at Department of Cell Biology, Graduate School of Medicine Osaka University and Faculty of Medicine Universitas Padjadjaran. The experimental animal was mice embryo gathered 17.5-days postcoitus. Enzymatic and mechanical methods collected primary hippocampal cells. The cells counted and cultured, which later were observed to see neuron differentiation. The average number of culture cells from 3 embryonic's hippocampus were $2.39 \times 10^{6}$. Neuron differentiation observed on the first day and more visible and numerous on the third day after plating. In conclusion, primary hippocampal cell culture using hippocampus from one hemisphere of embryonic mice brain showed a sufficient number of cells to carry out research and showed neuron differentiation.
\end{abstract}

Key words: Hippocampus, neuron, primary cell culture

\section{Kultur Sel Primer Hipokampus dan Penggunaannya dalam Riset Kedokteran}

\begin{abstract}
Abstrak
Penelitian dalam neurobiologi dapat dilakukan secara in vitro dan in vivo. Penelitian secara in vivo sangat berdampak hasilnya, namun sulit dan memakan waktu yang lama. Kultur sel primer hipokampus banyak digunakan dalam penelitian neurobiologi seperti melihat mekanisme protein seluler, serta aktivitas dan karakteristik neuron. Hasil penelitian yang dilakukan pada kultur sel ini akan sangat bermanfaat dalam menemukan proses suatu penyakit, efek suatu zat terhadap sel saraf, dan kemampuan belajar serta memori. Akan tetapi, saat ini di Indonesia kultur sel primer hipokampus masih jarang dan sulit dilakukan. Tujuan penelitian ini adalah menunjukkan bahwa kultur sel hipokampus primer dapat dilakukan dan dikembangkan di Indonesia, serta meninjau penerapannya dalam riset kedokteran. Penelitian ini merupakan studi eksperimental dengan mengoleksi neuron dari hipokampus hewan coba yang dilakukan pada tahun 2015-2018 di Department of Cell Biology, Graduate School of Medicine Osaka University dan Fakultas Kedokteran Universitas Padjadjaran. Hewan coba berupa embrio mencit hari ke17,5 pascakoitus. Sel primer hipokampus dikoleksi untuk dihitung dan dikultur menggunakan metode enzimatik dan mekanik. Observasi neuron pada kultur dilanjutkan dengan mengamati diferensiasi neuron. Rerata jumlah sel kultur dari 3 hipokampus adalah $2,39 \times 10^{6}$. Diferensiasi neuron sudah tampak pada hari pertama dan makin jelas serta tampak pada hari ketiga pascapenanaman. Simpulan, kultur sel primer hipokampus menggunakan hipokampus dari salah satu sisi hemisfer otak menunjukkan jumlah sel yang cukup untuk melakukan suatu penelitian dan menunjukkan diferensiasi dari neuron.
\end{abstract}

Kata kunci: Hipokampus, kultur sel primer, neuron

Received: 11 December 2018; Revised: 4 May 2019; Accepted: 5 May 2019; Published: 7 May 2019

Correspondence: Nur Atik, MD, Ph.D. Department of Biomedical Sciences, Faculty of Medicine, Universitas Padjadjaran. Jln. Raya Bandung-Sumedang km 21, Jatinangor, Sumedang 45363, West Java, Indonesia. Mobile: +6281280956825. E-mail: n.atik@unpad. ac.id 


\section{Introduction}

Neuroscience is a branch of science that studies about neurology, psychology, and biology. Neuroscience also develops along with other branches of science such as anatomy, physiology, biochemistry, and pharmacology of the brain and nerves. ${ }^{1}$ The study in these fields can be performed in vitro and in vivo. In vivo studies can be done, but it is difficult and complicated. In vitro studies using neuron is very useful for observing the function, mechanism, and structure of the neuron. There are several ways to culture neuron, for example, by using cell lines or primary cell culture. ${ }^{2,3}$

Currently, cell lines are instrumental in neuronal cultures because cell lines are easy to culture, generate numerous cells that immortal, and homogenous. There are several cell lines currently in use, such as human $\mathrm{SH}_{-} \mathrm{SY}_{5} \mathrm{Y}$ cell lines. These cells have derived from the parental metastatic bone tumor cell line SK$\mathrm{N}-\mathrm{SH}$ by the subcloning cell. These cells have a similar characteristic with neuroblast. ${ }^{2,4} \mathrm{~A}$ human neuronally committed teratocarcinoma cell line called NT2 cell or Ntera can be used in neuronal cultures by treatment with retinoic acid or inhibitor of mitosis. ${ }^{2,5}$ Rat cell lines that derived from a pheochromocytoma of adrenal medulla called PC12., ${ }^{2,6}$ Although cell lines have various advantages, these cells have a significant disadvantage because the cells have a different physiological characteristic with the neuron in vivo. The differences can lead to a different result of the study. ${ }^{2,7}$

Primary cell culture does not come from the tumor cell, and the structure is similar to neuron in vivo. ${ }^{2}$ There are several primary cell culture; one of them is primary hippocampal cell. The primary hippocampal cell obtained by culturing neuron from the hippocampus. Through this cell, learn about cell structure, function protein in the neuron, the pathogenesis of the disease, the effect of the drug on neuron and theories about memory and learning. ${ }^{8-12}$ Currently, in Indonesia, primary hippocampal cell culture is rarely done because of a complicated and immortal cell. However, the primary hippocampal cell has an advantage compared to the cell lines such as the characteristic of primary hippocampal cell resemble nerve cell in vivo. ${ }^{2}$ The purpose of this study was to demonstrate that primary hippocampal cell culture can be done and developed in Indonesia and to review the application of it in medical researches.

\section{Methods}

This study design was an experimental study by obtaining neuron from mice embryos was conducted in 2015-2018 at the Department of Cell Biology, Graduate School of Medicine, Osaka University, Japan and Faculty of Medicine, Universitas Padjadjaran, Bandung, Indonesia. Animals were treated according to the guidelines of the Animal Experimentation Committee of Osaka University (approval number: 21-045-0). ${ }^{13}$ Animals have given 12:12-h light-dark cycle with controlled humidity and temperature and free access to food and water. In this study, one male mouse and three female mice prepared. They prepared to copulating process. In the morning, a vaginal plaque was observed from the female mice to confirm mating process had occurred. Female mice that have vaginal plaque was separated and recorded as pregnant on the first day. ${ }^{14}$ After 17.5 days, the female mice sacrificed by cervical dislocation. ${ }^{15}$

Primary hippocampal cell culture performed according to the previous journal. ${ }^{11}$ In brief, the embryo counted, and the brain collected from each embryo. The hippocampus separated from the brain. They were transferred to $1 \mathrm{~mL}$ of phosphate-buffered saline (PBS) containing 1\% bovine serum albumin (BSA), deoxyribonuclease (DNase), papain, and glucose in $15 \mathrm{~mL}$ Falcon tube and put it again on the ice. The Falcon tube was incubated in a water bath at $37^{\circ} \mathrm{C}$ for 20 minutes. Using Pasteur pipette, the solution was triturated five times and incubated in the water bath at $37^{\circ} \mathrm{C}$ for 15 minutes. Pipetting five times again, and wait for several times. All supernatant aspirated without aspirated the pellet. After centrifugation, they plated on $35-\mathrm{mm}$ dish pretreated with polyD-lysine and laminin. They were cultured in neurobasal medium supplemented with B27 and GlutaMAX at $37^{\circ} \mathrm{C}$ in humidified $5 \% \mathrm{CO}_{2}{ }^{11}$

The cells were counted using hemocytometer under a microscope. They spread into the $35 \mathrm{~mm}$ dish, which already coated with poly-D-lysine, laminin, and neurobasal medium $+10 \%$ fetal calf serum at $37^{\circ} \mathrm{C}$ and $5 \%$ humidity.

The cultured cells were observed under a stereotype microscope with a $20 \times$ magnification objective lens at 24, 48, and 72 hours after plating. The morphology of the cell was rated by 


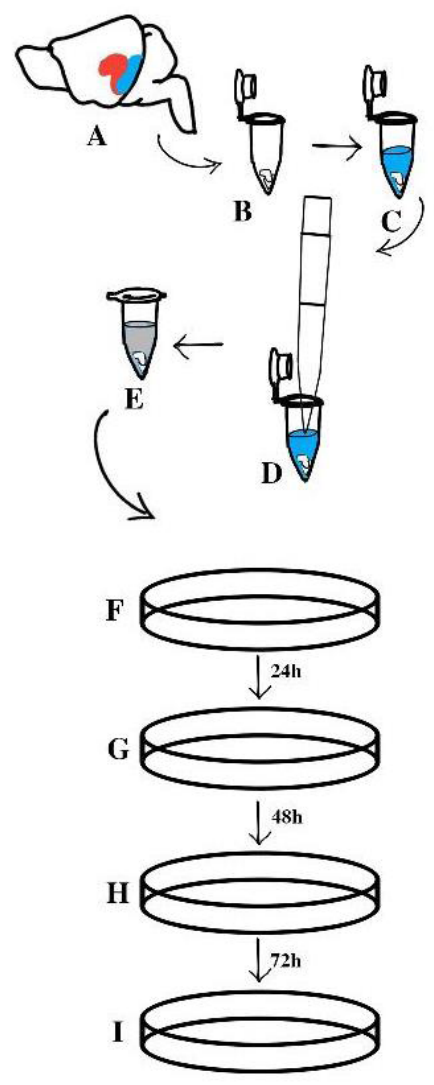

Figure 1 Culture Procedure

The schematic draw of the procedure. Hippocampal was collected from the fetal brain and proceed with the enzymatic procedures (A-E). Neurons were plated and observe sequentially $(\mathrm{F}-\mathrm{I})$
Table Number of Primary Hippocampal Cells

\begin{tabular}{ccc}
\hline $\begin{array}{c}\text { Number of } \\
\text { Hippocampus }\end{array}$ & $\begin{array}{c}\text { Number of } \\
\text { Cell }(\text { Cell } / \mathbf{m L})\end{array}$ & Mean \pm SD \\
\hline 1 & $2.35 \times 106$ & \\
2 & $2.71 \times 106$ & $(2.39 \times 106) \pm$ \\
3 & $2.11 \times 106$ & \\
\hline
\end{tabular}

measuring the neurite. Neurite was considered as axon if the length of the neurite was at least twice as long as any other process and was more than twice the diameter of the cell body. ${ }^{11,16}$

\section{Results}

The primary hippocampal cell that had been cultured were counted using hemocytometer under a microscope. The results presented in Table. The mean number of cells from 3 hippocampi were $2.39 \times 10^{6} \mathrm{cell} / \mathrm{mL}$.

Primary hippocampal cell observation was done by looking neuron morphology at first until the third day (Figure 2). Neuron differentiation observed on the first day as an elongation of neurite from the cell body. Neurite considered as axon or dendrite according to its length. Differentiation was more visible and numerous
24 hours
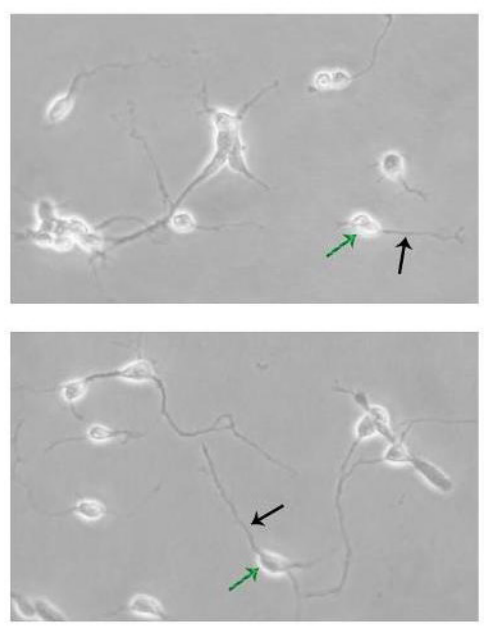

Figure 2 Neuronal Architecture

Micrographs of cultured hippocampal neurons at 24, 48, and 72 hours after plating to show neuron differentiation. Green arrow: cell body, black arrow: neurite
48 hours
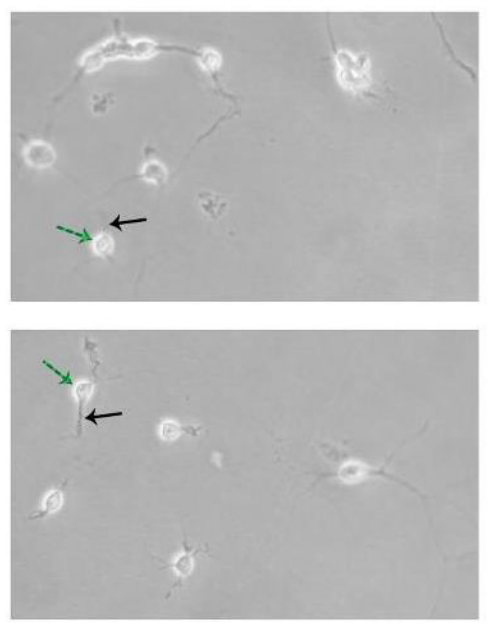

72 hours
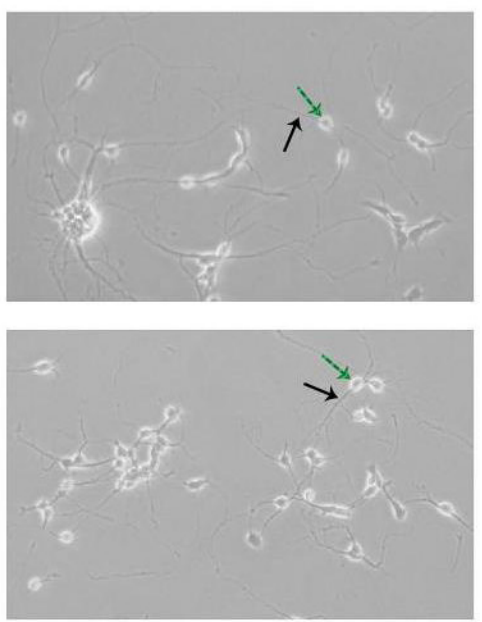
on the 72 hours after plating.

\section{Discussion}

Primary hippocampal cell culture is one of several methods to conduct a study in neuron. ${ }^{2,3}$ Currently, in Indonesia, optimization of primary hippocampal cell culture is rare and challenging to do. The benefits of this culture are prodigious. ${ }^{2}$ The cultured cells can use for study in many fields such as anatomy, physiology, biochemistry, pharmacology, and study about memory and learning. ${ }^{2,3,8-16}$ By isolating and developing neuron from this culture, cell to cell interaction, cell structure, and protein in neuron observed. ${ }^{2,3}$ Although the cells derived from this culture are not immortal and limited; they are similar to neuron in vivo. The results of the study come from using these cells are more significant.

From our study, the mean number of primary hippocampal cell culture was $2.39 \times 10^{6}$ cells/ $\mathrm{mL}$. The cell observation under the microscope showed neuronal differentiation, especially after 72 hours after plating on the dish. Therefore, these results indicate that even though primary hippocampal cell culture is difficult, it is possible to do in Indonesia.

The applications of primary hippocampal cell culture in medical practices are numerous. Primary hippocampal cell culture could be used to discover the mechanism of a disease such as Alzheimer's disease. Hippocampal cell culture was used to discover the presence of extracellular fibrillar $\mathrm{A} \beta$ in amyloid plaque, and intraneuronal neurofibrillary tangles consist of aggregated hyperphosphorylated tau, and elevated brain levels of soluble amyloid-beta derived diffusible ligands (ADDLs). 9 The study found that in Alzheimer's disease, tau phosphorylation cultures of hippocampal neurons stimulated by ADDLs. Other studies using primary hippocampal cell culture showed that tau had a dendritic function. Tau-targeted NMDA receptor in postsynaptic, it has direct implications for pathogenesis and treatment of Alzheimer's disease. ${ }^{17}$

Primary hippocampal cell culture is also used to discover the role and mechanism of protein in the neuron. One study with primary hippocampal cell culture discovered that the role of vesicleassociated membrane protein 7 (VAMP7) or tetanus insensitive vesicle-associated membrane protein (TI-VAMP) on the neuronal outgrowth. The study used primary hippocampal cells from
VAMP7 knockout (KO) mice and discovered that axonal elongation in $\mathrm{KO}$ mice was impaired. The study did not find the degradation of neuron-glia cell adhesion molecule (NgCAM) by immunofluorescence micrograph. ${ }^{10}$ Other study using this culture, discovered that depletion of PKD1 and PKD2 affects axonal elongation. This study showed the role of PKD1 and PKD2 in axonal elongation. ${ }^{11}$

Primary hippocampal cell culture was used to discover the protective effect of salidroside for neuron. Salidroside has taken from Rhodia rosea. This study showed salidroside had protection effect to $\mathrm{H}_{2} \mathrm{O}_{2}$ by reducing the activity of caspase- 3 , production of nitrite oxide (NO) and NO synthase. This effect can be used to develop salidroside as an agent to prevent or treat the neuronal injury in neurodegenerative disease. ${ }^{12}$ Besides, other studies of peptides that have a function similar to brain-derived neurotrophic factor (BDNF) were also conducted to test therapeutic effects in disorders with BDNF levels. It found that BDNF peptides were nontoxic to nerve cells in vitro in the hippocampal primary culture. Also, B-3 peptide that is one of the five tetrapeptides tested has a potential neuroprotective effect on the toxicity of $\mathrm{H}_{2} \mathrm{O}_{2} \cdot{ }^{18}$

\section{Conclusions}

Primary hippocampal cell culture using hippocampus from one hemisphere of embryonic mice brain showed a sufficient number of cells to carry out research and showed neuron differentiation. This study also demonstrates that primary hippocampal cell culture can be done and developed in Indonesia.

\section{Conflict of Interest}

The authors declare no conflict of interests.

\section{Acknowledgement}

Authors thank all members of the Department of Cell Biology, Graduate School of Medicine Osaka University, Japan.

\section{References}

1. Goswami U. Neuroscience and education. Br J Educ Psychol. 2004;74(Pt 1):1-14.

2. Gordon J, Amini S, White MK. General 
overview of neuronal cell culture. Methods Mol Biol. 2013;1078:1-8.

3. Xiao Z, Peng J, Yang L, Kong H, Yin F. Interleukin-1 $\beta$ plays a role in the pathogenesis of mesial temporal lobe epilepsy through the $\mathrm{PI} 3 \mathrm{~K} / \mathrm{Akt} / \mathrm{mTOR}$ signaling pathway in hippocampal neurons. J Neuroimmunol. 2015;282:110-7.

4. Kovalevich J, Langford D. Considerations for the use of $\mathrm{SH}_{-} \mathrm{SY}_{5} \mathrm{Y}$ neuroblastoma cells in neurobiology. Methods Mol Biol. 2013;1078:9-21.

5. Podrygajlo G, Tegenge MA, Gierse A, PaquetDurand F, Tan S, Bicker G, et al. Cellular phenotypes of human model neurons (NT2) after differentiation in aggregate culture. Cell Tissue Res. 2009;336(3):439-52.

6. Ye J, Liu Z, Wei J, Lu L, Huang Y, Luo L, et al. Protective effect of SIRT1 on toxicity of microglial-derived factors induced by LPS to PC12 cells via the p53-caspase-3dependent apoptotic pathway. Neurosci Lett. 2013;553:72-7.

7. Kaur G, Dufour JM. Cell lines: valuable tools or useless artifacts. Spermatogenesis. 2012;2(1):1-5.

8. Seibenhener ML, Wooten MW. Isolation and culture of hippocampal neurons from prenatal mice. J Vis Exp. 2012;(65):3634.

9. Danysz, W. and Parsons, C.G. Alzheimer's disease, $\beta$-amyloid, glutamate, NMDA receptors and memantine-searching for the connections. $\mathrm{Br} \mathrm{J}$ Pharmacol. 2012;167(2):324-52.

10. Sato M, Yoshimura S, Hirai R, Goto A, Kunii $\mathrm{M}$, Atik N, et al. The role of VAMP7/TI-VAMP in cell polarity and lysosomal exocytosis in vivo. Traffic. 2011;12(10):1383-93.

11. Avriyanti E, Atik N, Kunii M, Furumoto $\mathrm{N}$, Iwano T, Yoshimura S, et al. Functional redundancy of protein kinase D1 and protein kinase D2 in neuronal polarity. Neurosci Res.
2015;95:12-20.

12. Zhang J, Zhen YF, Pu-Bu-Ci-Ren, Song LG, Kong WN, Shao TM, et al. Salidroside attenuates beta amyloid-induced cognitive deficits via modulating oxidative stress and inflammatory mediators in rat hippocampus. Behav Brain Res. 2013;244:70-81.

13. Teoh JJ, Iwano T, Kunii M, Atik N, Avriyanti $\mathrm{E}$, Yoshimura S, et al. BIG1 is required for the survival of deep layer neurons, neuronal polarity, and the formation of axonal tracts between the thalamus and neocortex in developing brain. PLoS One. 2017;12(4):e0175888.

14. Heyne GW, Plisch EH, Melberg CG, Sandgren EP, Peter JA, Lipinski RJ. A simple and reliable method for early pregnancy detection in inbred mice. J Am Assoc Lab Anim Sci. 2015;54(4):368-71.

15. Institutional Animal Care and Use Committee, The University of Texas at Austin. Guidelines for the use of cervical dislocation for rodent euthanasia [Internet]. research.utexas.edu. 2018 [cited 2018 August 23]. Available from: https://research.utexas.edu/wp-content/ uploads/sites/3/2018/04/guidelineo4.pdf.

16. Yin DM, Huang YH, Zhu YB, Wang Y. Both the establishment and maintenance of neuronal polarity require the activity of protein kinase D in the Golgi apparatus. J Neurosci. 2008;28(35):8832-43.

17. Ittner LM, Ke YD, Delerue F, Bi M, Gladbach A, van Eersel J, et al. Dendritic function of tau mediates amyloid- $\beta$ toxicity in Alzheimer's disease mouse models. Cell. 2010;142(3):387-97.

18. Cardenas-Aguayo Mdel C, Kazim SF, Grundke-Iqbal I, Iqbal K. Neurogenic and neurotrophic effects of BDNF peptides in mouse hippocampal primary neuronal cell cultures. PLoS One. 2013;8(1):e53596. 